NBER WORKING PAPER SERIES

\title{
OPTIMAL TARIFFS AND TRADE POLICY FORMATION: U.S. EVIDENCE FROM THE SMOOT-HAWLEY ERA
}

\author{
Douglas A. Irwin \\ Anson Soderbery \\ Working Paper 29115 \\ http://www.nber.org/papers/w29115 \\ NATIONAL BUREAU OF ECONOMIC RESEARCH \\ 1050 Massachusetts Avenue \\ Cambridge, MA 02138 \\ July 2021
}

This paper has benefitted immensely from conversations with Matt Grant, Andrew Greenland, Ahmad Laskaripour, Marcelo Olarreaga, Robert Staiger and seminar participants. We thank Mason Reasner for invaluable research assistance. The views expressed herein are those of the authors and do not necessarily reflect the views of the National Bureau of Economic Research.

At least one co-author has disclosed additional relationships of potential relevance for this research. Further information is available online at http://www.nber.org/papers/w29115.ack

NBER working papers are circulated for discussion and comment purposes. They have not been peer-reviewed or been subject to the review by the NBER Board of Directors that accompanies official NBER publications.

(C) 2021 by Douglas A. Irwin and Anson Soderbery. All rights reserved. Short sections of text, not to exceed two paragraphs, may be quoted without explicit permission provided that full credit, including $(\odot$ notice, is given to the source. 
Optimal Tariffs and Trade Policy Formation: U.S. Evidence from the Smoot-Hawley Era Douglas A. Irwin and Anson Soderbery

NBER Working Paper No. 29115

July 2021

JEL No. F13,F14

\title{
ABSTRACT
}

This paper examines the political economy of U.S. trade policy around the time of the SmootHawley tariff of 1930, a period when policy was unconstrained by trade agreements. We consider a model of politically-optimal trade policy for a large country that can influence its terms of trade and where workers and firms lobby for protection. The predictions of the model hinge on import demand and export supply elasticities, which we estimate using detailed U.S. import data from 1927-35, as well as industry lobbying data. We find that tariff levels are largely determined by firm lobbies, but about about 5 percentage points of the tariffs are explained by terms of trade considerations. Decomposing the politically-optimal tariff in 1931 reveals an intensification of demand for protection by workers in the Smoot-Hawley tariff.

\author{
Douglas A. Irwin \\ Department of Economics \\ Dartmouth College \\ Hanover, NH 03755 \\ and P̧eterson Institute for International Economics \\ and also NBER \\ douglas.irwin@dartmouth.edu \\ Anson Soderbery \\ 100 S Grant St \\ Krannert School of Management \\ Rawls 4035 \\ West Lafayette, IN 47907 \\ asoderbe@purdue.edu
}




\section{Introduction}

What objective is a government trying to achieve in setting import tariffs? The answer hinges in part on whether a country bases its policy on purely domestic factors (in a noncooperative setting) or negotiates with other countries to reach agreements on tariffs (in a cooperative setting). Since World War II, the United States, the European Community, and other leading countries have bound their tariffs in cooperative trade agreements through the General Agreement on Tariffs and Trade (GATT). Bagwell and Staiger (2011) view these agreements as a way of escaping a terms-of-trade driven prisoner's dilemma in which, in the absence of cooperation, each country would impose optimal tariffs and reduce trade to suboptimal levels. An alternative hypothesis by Maggi and Rodríguez-Clare (2007) is that governments sign such agreements to commit themselves to lower tariffs in the face of special interest lobbying. Of course, as Grossman and Helpman (1995) suggest, governments may be responding to both terms-of-trade considerations and domestic interests in negotiating trade agreements. Although it is difficult to pierce the veil of negotiations to understand the motivations driving trade agreements, some progress has been made in understanding the bargaining process (Bagwell et al. (2020)).

But what factors would drive government behavior in the absence of such agreements when countries have complete autonomy in setting tariff rates? It could be for purely domestic reasons, partly based on social welfare and partly based on industry influence, as in the Grossman and Helpman (1994) "protection for sale" model. Or it could be the desire to impose optimal tariffs that maximize the national advantage through terms-of-trade manipulation. It is difficult to answer this question because the existence of cooperative trade agreements in recent decades does not allow us to observe unconstrained, non-cooperative trade policies by major countries such as the United States that might have both a termsof-trade motive for tariffs and also be susceptible to producer and consumer interests. For example, Goldberg and Maggi (1999) test the protection-for-sale model on U.S. data (using non-tariff barrier coverage ratios from the 1980s because tariffs were set cooperatively) but do not take into account market-power considerations. Broda et al. (2008) estimate trade 
elasticities and calculate optimal tariffs for a small sample of countries that were not members of the World Trade Organization (WTO) and hence formally unconstrained in their tariff setting. They find surprisingly high estimated optimal tariffs, given that their sample consists of small developing countries, but they do not fully explore political economy factors, only including the inverse import-penetration ratio in some of their analysis as a proxy for such effects. Similarly, Bagwell et al. (2020) look at a sample of small countries (China being an exception) that had unconstrained policies prior to their WTO membership to see how accession changed their tariff structure, but they do not focus on the underlying determinants of those pre-negotiation tariffs. By contrast, Ossa (2014) provides data-based (2007 benchmark) simulation evidence for countries that are more plausibly "large," suggesting that the non-cooperative U.S. tariff would be 60 percent based on terms-of-trade factors and 57 percent based on terms-of-trade and domestic lobbying factors combined. In sum, it is difficult to find large countries today that would have a strong terms-of-trade motive for optimal tariffs and yet are not members of the GATT/WTO and hence unconstrained in their ability to set tariffs as they please.

This paper seeks to shed light on non-cooperative tariff setting in a large country by looking at the United States in a unique historical period when its tariff policy was unconstrained by international agreements and was therefore set purely for domestic reasons, not in multilateral negotiations. We focus on the late 1920s and early 1930s, around the time of the Smoot-Hawley tariff of 1930, a period when tariffs were the only major instrument of trade policy (import quotas were not yet employed) and industry lobbying was fairly transparent as revealed in the Congressional hearings on the tariff schedule. At the same time, as the world's largest economy, the United States was likely to have had market power vis-a-vis imports and therefore may have benefited from an optimal tariff in the absence of retaliation. ${ }^{1}$ The availability of highly detailed import data allows us to estimate trade elasticities at what today would be considered the 4-digit level. Thus, in this historical period when the U.S. policymakers (members of Congress) had complete discretion in setting tariffs, we can

\footnotetext{
${ }^{1}$ Although the US did not anticipate it, Mitchener et al. (2021) shows that there was significant foreign retaliation against the Smoot-Hawley tariff.
} 
examine whether tariffs were set on the basis of market power (trade elasticities) or domestic political factors (industry lobbying) and to determine the relative weights placed on both.

This paper is organized as follows. Section 2 provides a basic framework for thinking about optimal tariff setting for a large country that also faces domestic political pressure to protect certain industries. What we call the political-optimal tariff takes into account terms of trade effects (the standard optimal tariff), domestic political economy considerations (firm and worker lobbying), and social welfare (consumer well-being). Section 3 describes the trade data and the method of estimating elasticities that provides the basis of our analysis. The combination of detailed elasticity estimates allows us to calculate the optimal tariff at a the 4-digit industry level. We find that the median (inverse) export supply elasticity implies a median optimal tariff of 14 percent and that there is a weak but positive relationship between the implied optimal and actual applied tariff. In Section 4 we introduce lobbying and find that these political-economy determinants of tariffs slightly dominate the terms of trade factors in explaining the pattern of tariffs across goods. We also decompose the applied tariffs into lobbying and terms of trade components, suggesting that about half of the tariff level is due to firm lobbying with the remainder split between worker lobbies and terms-of-trade factors. ${ }^{2}$

\section{Optimal Tariffs and Lobbying: Theory}

We focus on a particular historical period in which the United States (i) had complete autonomy in setting its tariff (i.e., policymakers were unconstrained by any cooperative agreements on tariff levels), (ii) was likely to have had substantial market power in trade, and (iii) had domestic producers and workers lobbying for tariffs on particular products. To frame our discussion, we consider a trade policy model in the spirit of Grossman and Helpman (1995) where an importing country has market power and industry lobbies make

\footnotetext{
${ }^{2}$ This paper will not discuss the historical background to the Smoot-Hawley tariff except insofar as it bears upon the issues analyzed in this paper; for further details, see Irwin (2011) and Irwin (2017).
} 
contributions for protection. ${ }^{3}$ First, we assume a fraction of workers $\left(\alpha_{l}\right)$ receive specific factor rents $\left(\pi_{k}\right)$ and decide how much to contribute to a local lobby. Imports from country $i$ of good $k$ are denoted by $x_{k}$, and total consumption of good $k$ by $d_{k}$. A worker in industry $k$ thus obtains welfare that is the sum of their wages (normalized to unity), distributed tariff revenue $\left(r\left(\tau_{k}\right)\right)$ and consumer surplus $\left(s\left(\tau_{k}\right)\right)$,

$$
W_{l, k}=1+\pi_{l, k}+\alpha_{l}[\underbrace{\sum_{k}\left(\tau_{k}-1\right) p_{k}^{*} x_{k}}_{r\left(\tau_{k}\right)}+\underbrace{u\left(d_{k}\left(p_{k}\right)\right)-p_{k} d_{k}}_{s\left(\tau_{k}\right)}],
$$

where $\tau_{k}$ are tariffs levied on product $k$ such that the consumption price $\left(p_{k}\right)$ is the product of shipped prices $\left(p_{k}^{*}\right)$ and the tariff: $p_{k}=\tau_{k} p_{k}^{*}$.

In addition to worker organized lobbies, all domestic firms decide to pay a portion of their excess profits to fund a lobby representing firm interests. We treat the payoff to firms as a portion of their fixed costs less contributions. That is to say, firms' payoffs are determined by their excess profitability used to cover fixed costs and political contributions. Denoting firms' total fixed costs by $F C_{f}$ and the fraction of excess profits paid by the firm as $\alpha_{f}$ yields the payoff function,

$$
W_{f, k}=F C_{f}-\left(1-\alpha_{f}\right)\left[p_{k} q_{f, k}-\pi_{f, k}-1\right]
$$

where $q_{f, k}$ is firm output, such that $q_{k}=\sum_{f} q_{f, k}$ is industrial output and $d_{k}=x_{k}+q_{k}$ is total consumption. We will assume domestic firms are identical in terms of marginal costs and compete under monopolistic competition. Consequently firm prices and output are identical. However, we allow for the possibility that fixed costs are firm specific such that a subset of firms can afford to contribute to the lobby.

The government payoff is then the sum of worker earnings, tariff revenues, consumer

\footnotetext{
${ }^{3}$ As already noted, Grossman and Helpman (1994) considers industry lobbying but in a small country context.
} 
surplus, and firm profits across all goods:

$$
W^{G}=1+\sum_{k} \pi_{k}+r\left(\tau_{k}\right)+s\left(\tau_{k}\right)+\sum_{k}\left(\sum_{f} p_{k} q_{k}-\pi_{f, k}-1-F C_{f}\right) .
$$

In order to determine the politically-optimal tariff policy we follow Grossman and Helpman (1995). A social planner thus chooses the tariff that maximizes the objective function,

$$
\Omega=a W^{G}+\sum_{l} W_{l, k}+\sum_{f} W_{f, k},
$$

where $a \in[0, \infty)$ is the importance of the government payoff relative to workers and firms. We will assume that each product enters independently such that the planner chooses an optimal tariff good by good. Choosing the tariff that maximizes the planner's problem for $\operatorname{good} k$ is then,

$$
\underset{\tau_{k}}{\operatorname{argmax}}\left(\begin{array}{c}
a\left[1+\sum_{k} \pi_{k}+r\left(\tau_{k}\right)+s\left(\tau_{k}\right)+\sum_{k}\left(\sum_{f} p_{k} q_{k}-\pi_{f, k}-1-F C_{f}\right)\right] \\
+1+\sum_{l} \pi_{l, k}+\alpha^{L}\left[\sum_{k}\left(\tau_{k}-1\right) p_{k}^{*} x_{k}+u\left(d_{k}\left(p_{k}\right)\right)-p_{k} d_{k}\right] \\
+\sum_{f} F C_{f}-\left(1-\alpha^{F}\right)\left[p_{k} q_{k}-\pi_{f, k}-1\right]
\end{array}\right)
$$

The fraction of workers that join the lobby is $\alpha^{L} \equiv \Sigma_{l} \alpha_{l} \in[0,1]$, and the average of firm excess profits contributed to lobbying is $\alpha^{F} \equiv \Sigma_{f} \alpha_{f} \in[0,1]$.

Choosing the tariff that maximizes welfare yields a politically-optimal tariff $\left(\tau_{k}^{*}\right)$ for every good $k$ :

$$
\tau_{k}^{*}-1=\omega_{k}+\frac{\left(I_{k}^{L}-\alpha^{L}\right)+\sigma_{k} I_{k}^{F}\left(1-\alpha^{F}-a\right)}{a+\alpha^{L}} \frac{z_{k}}{\sigma_{k}},
$$

where $I_{k}^{L}$ and $I_{k}^{F}$ are indicators for whether or not worker and firm lobbies, respectively, are politically organized. Import penetration is denoted by $z_{k}=x_{k} / q_{k}, \sigma_{k}$ is the import demand elasticity, and $\omega_{k}$ is the (inverse) foreign export supply elasticity. 
In essence, what we refer to as the politically-optimal tariff is a combination of two components, the term-of-trade factor (captured by the foreign export supply elasticity) and the political-economy factor (which depends on lobbying by firms and workers, the import demand elasticity, import penetration, and the government's weight on social welfare). Our equation (5) is essentially the same as Grossman and Helpman (1995) equation (16) except that we have firm lobbies as well.

An empirical assessment of this framework requires estimates of the elasticity of import demand $\sigma_{k}$, the elasticity of (inverse) foreign export supply $\omega_{k}$, and indicators of whether workers and firms lobby the government over policy, $I_{k}^{L}$ and $I_{k}^{F}$, respectively. The next section provides details on these matters.

\section{Trade Data and Elasticity Estimates}

The key to providing a structural estimate of the model presented above is data on imports and domestic production at the product level along with estimates of demand and supply elasticities. Estimates of the elasticity of (domestic) import demand and (foreign) export supply require detailed data on the price and quantity of imports by source country. The annual volumes "Foreign Commerce and Navigation of the United States," published by the Department of Commerce, provides such data. We digitized section 4 of these reports for the years 1927-1935, covering the years around the Smoot-Hawley tariff change. In each year, this table reports the value of imports for a particular commodity or good by country, along with the quantity imported by country (at what today would be roughly the 4-digit level; e.g., raw silk from Japan, perennially the largest US import in our data, is code 3702). This allows a unit-value price to be calculated for each product in question. The section also reports the ad valorem tariff equivalent for each product category in each year. (Many import duties at this time took the form of specific duties.) As dictated by the theory, we also require domestic production data at the product level in order to construct import penetration measures. These data are only available every other year through the Census of Manufactures and the Census of Agriculture. 
Table 1 reports the summary statistics of the combined trade and production data every other year from 1927-1935. The value, volume, and unit value of imports fall considerably after 1930 with the onset of deflation and Great Depression. The median tariff also rises after 1929, a combination of the higher rates in the 1930 legislation and the lower import prices acting on specific duties (Irwin (1998)). The average number of imported goods is between 650-750 and the average number of varieties is between 9,000-14,000 (representing the average number of countries from which the United States imports a particular good). The average number of varieties falls during this period, which has implications for the welfare gains from trade.

Table 1: Summary Statistics of Imports

\begin{tabular}{llcccccc}
\hline & & Sample & 1927 & 1929 & 1931 & 1933 & 1935 \\
\hline \multirow{3}{*}{ Total Imports } & Value (\$Bill) & 2.43 & 3.68 & 3.98 & 1.81 & 1.23 & 1.61 \\
& Quantity (Bill Lbs) & 25.75 & 30.02 & 34.31 & 23.37 & 22.14 & 21.21 \\
& Median Unit Value $(\$)$ & 0.24 & 0.29 & 0.30 & 0.21 & 0.19 & 0.20 \\
\hline \multirow{2}{*}{ Domestic Production } & Total Value (\$Bill) & 49.79 & 58.90 & 73.08 & 46.90 & 33.63 & 45.34 \\
\hline \multirow{2}{*}{ Tariffs } & Mean & $26.78 \%$ & $19.97 \%$ & $19.63 \%$ & $35.15 \%$ & $29.39 \%$ & $27.49 \%$ \\
& Median & $18.40 \%$ & $15.77 \%$ & $14.15 \%$ & $19.49 \%$ & $19.87 \%$ & $20.06 \%$ \\
& IQR & $40.02 \%$ & $30.03 \%$ & $30.63 \%$ & $49.75 \%$ & $44.03 \%$ & $43.02 \%$ \\
\hline \multirow{2}{*}{ Products } & 673 & 687 & 745 & 700 & 671 & 656 \\
& Goods & 11207 & 13598 & 13392 & 10314 & 9435 & 10785 \\
\hline
\end{tabular}

Notes: IQR is the inter-quartile range. Products are 4-digit codes. Varieties are unique 4-Digit product exporter pairs. "Sample" is the average over all years in the data.

As Feenstra (1994) and Broda and Weinstein (2006) show, the price and quantity data can be used to provide structural estimates of import demand and export supply elasticities. However, Soderbery (2015) demonstrates that there are significant biases in these methods. He develops a hybrid estimator that corrects for small sample biases and constrained search inefficiencies and finds that the standard methods tend to overstate the median demand elasticity. Overestimating import demand elasticities carries a host of implications in quantifying welfare. Most relevant in our setting is that high import demand elasticities imply low optimal tariffs. 
This paper uses the Soderbery (2015) method to estimate trade elasticities using the import data from 1927-35. At this point, we give specific functional forms to consumer preferences and export supply, with the goal of maintaining consistency with the literature and facilitate quantification. A representative consumer in each country maximizes her utility by choosing imports and domestic consumption. Following the standard in the literature in a way that is consistent with the lobbying model, assume consumers aggregate over the composite domestic $(D)$ and imported $(X)$ goods. The subutility derived from the composite imported good will be given by a CES aggregation across imported varieties with a good-importer specific elasticity of substitution given by $\sigma_{k}$. Note that we suppress importer subscripts as the United States is our sole focus. Imports of the particular variety of good $k$ from country $j$ are denoted by $x_{j k}$. Import demand is also augmented by a variety specific taste parameter $b_{j k}$. Consumers purchase a numeraire, $c_{0}$ from the policy side of the model, and aggregate their consumption through a Cobb-Douglas function. ${ }^{4}$ Under these assumptions, the utility obtained by a representative consumer can be written as:

$$
U=c_{0}+\xi_{X} \sum_{k \in K} \phi_{k} \log \left(\left(\sum_{j \in J_{k}}\left(b_{j k}\right)^{\frac{1}{\sigma_{k}}}\left(x_{j k}\right)^{\frac{\sigma_{k}-1}{\sigma_{k}}}\right)^{\frac{\sigma_{k}}{\sigma_{k}-1}}\right)+\xi_{D} \log (D) .
$$

The importer consumes fixed shares $\xi_{D}$ and $\xi_{X}$ of domestic and imported goods, respectively. Furthermore, the imported composite is formed by consumption of fixed shares of each imported good given by Cobb-Douglas parameters $\phi_{k}$. The separability of utility allows us to focus on prices and consumption of imported goods in the estimation. ${ }^{5}$ This specification also implies that trade policy affects goods independently, which was assumed in the trade

\footnotetext{
${ }^{4}$ The numeraire abstracts away from quantifying wage effects in order to focus on trade flows and policy as well as product elasticities. Our preferences also rule out income effects in the model. Both assumptions prevail in the literature (c.f, Broda, Limão and Weinstein (2008)) but none are necessary for estimation. The structural assumption facilitating estimation is the CES form of the imported variety nest.

${ }^{5}$ Finally note, the form of the domestic consumption nest is also irrelevant for estimation as long as it is independent from the import nest. This assumption is induced by data availability. If we observed prices and quantities of domestic sales we would include them in the import nest and estimation. Unfortunately such data (specifically quantities and prices) are not available in this time period and we are forced to assume they are separable (Cobb-Douglas being the most convenient).
} 
policy component of the theory and is consistent with what we know about Congressional tariff-setting at the time.

Foreign varieties are exported following the iso-elastic export supply curve proposed by Feenstra (1994):

$$
p_{j k}^{*}=\exp \left(\eta_{j k}\right)\left(x_{j k}\right)^{\omega_{k}}
$$

where $\omega_{k}$ is the inverse export supply elasticity, $\eta_{j, k}$ is a technology parameter, $p_{j k}^{*}$ are shipped prices and $x_{j k}$ are total imports from country $j$.

In terms of estimation, we follow the Soderbery (2015) modification of Feenstra (1994). We apply the heteroskedastic estimator of supply and demand that relies on time series variation in imported prices and quantities. The methodology addresses unobservables by first- and reference-country differencing; consistency depends on independence of supply $\left(\eta_{j k}\right)$ and demand $\left(b_{j k}\right)$ error terms.

To estimate supply and demand, we use detailed U.S. import data from every year 19271935. Although detailed tariff data are only available every other year from 1927-1935, our method of reference differencing eliminates the need for those data at an annual frequency, as the tariffs were applied uniformly across importers within the year. ${ }^{6}$ This allows us to apply the estimator to the full sample of trade data and incorporate the tariff data with the elasticities when we examine optimal policy.

This approach yields estimates of two key parameters: $\sigma_{k}$ (the elasticity of import demand) and $\omega_{k}$ (the inverse elasticity of foreign export supply) for each good $k$. Table 2 reports the mean, median, and inter-quartile range of the estimates for each year. The distribution of estimates across products has a long tail which explains the large wedge between the mean and median estimate; other researchers have also found the estimates of the export supply elasticities to be quite noisy across products. The mean estimated (inverse) export supply elasticity is about 7 whereas the median estimate is 0.175 , implying the median optimal

\footnotetext{
${ }^{6}$ Except for the occasional product from Cuba, which amount to small shares of within product trade and are not included in our analysis.
} 
import tariff (on terms of trade grounds) is 17.5 percent. Remarkably, this magnitude is also very close to Nicita et al. (2018), who estimate the median (inverse) export supply elasticity facing the United States to be 0.14, implying an optimal tariff of about 14 percent, based on detailed import data from 1988-2007. By contrast, using a simulation model benchmarked on 2007 data, Ossa (2014) calculates the optimal U.S. tariff to be about 60 percent.

Table 2: Elasticities across Industries

\begin{tabular}{|c|c|c|c|c|c|c|c|}
\hline & & Sample & 1927 & 1929 & 1931 & 1933 & 1935 \\
\hline \multirow{3}{*}{$\begin{array}{c}\text { Inverse Export } \\
\text { Supply Elasticity: } \\
\omega_{k}\end{array}$} & Mean & 7.026 & 6.142 & 7.164 & 7.348 & 7.480 & 7.040 \\
\hline & Median & 0.175 & 0.178 & 0.174 & 0.175 & 0.178 & 0.175 \\
\hline & IQR & 0.486 & 0.450 & 0.490 & 0.487 & 0.500 & 0.502 \\
\hline \multirow{3}{*}{$\begin{array}{l}\text { Import Demand } \\
\text { Elasticity: } \sigma_{k}\end{array}$} & Mean & 5.950 & 6.564 & 6.164 & 5.770 & 5.650 & 5.936 \\
\hline & Median & 2.860 & 2.906 & 2.906 & 2.858 & 2.826 & 2.819 \\
\hline & IQR & 2.506 & 2.650 & 2.646 & 2.416 & 2.355 & 2.479 \\
\hline
\end{tabular}

Notes: IQR is the inter-quartile range. Elasticities are truncated at 100 for exposition as is customary in the literature.

Table 2 also reports the estimated import demand elasticities. The median import demand elasticity (in absolute value) is roughly 2.9 and is also fairly consistent across years. Notice that since import demand and export supply elasticities are themselves constant, variation in their statistical moments reflect churning in goods over time. The mean elasticity of import demand $\sigma_{k}$ is about 6 which is slightly larger than the mean of 5.2 estimated for 1993-2007 as reported in Table 4 of Soderbery (2015).

Figures 1-4 present four ways of showing the relationship between the actual applied tariff and the implied optimal tariffs on terms of trade grounds. (For now, we are setting aside lobbying motives and assume that policymakers give zero weight to political contributions and firm lobbies are unorganized, $a \rightarrow \infty$ and $I_{k}^{F}=0$, implying $\tau^{*}=\omega$.) Figure 1 presents the median applied and optimal tariff across industries for the different years. At a first pass, the applied and optimal (terms of trade) tariffs seem to be surprisingly closely related, even before lobbying is considered. In general, the applied (non-cooperative) tariffs fall below the optimal level as suggested by the export supply elasticity. To summarize Figure 
1, Figure 2 uses a lowess to fit a curve through the raw medians. The major deviations of the inverse export supply elasticity and applied tariff are for products 26 (tobacco products), 83 (industrial chemicals) and 94 (toys and sporting goods). According to these results, the applied tariffs in these categories are much lower than the implied optimal (terms of trade) tariffs - we can see from Figure 1, these differences a mostly attributed to a relatively high inverse export supply elasticity estimate.

Figure 1: Tariffs Across Industries - Scatter of Medians

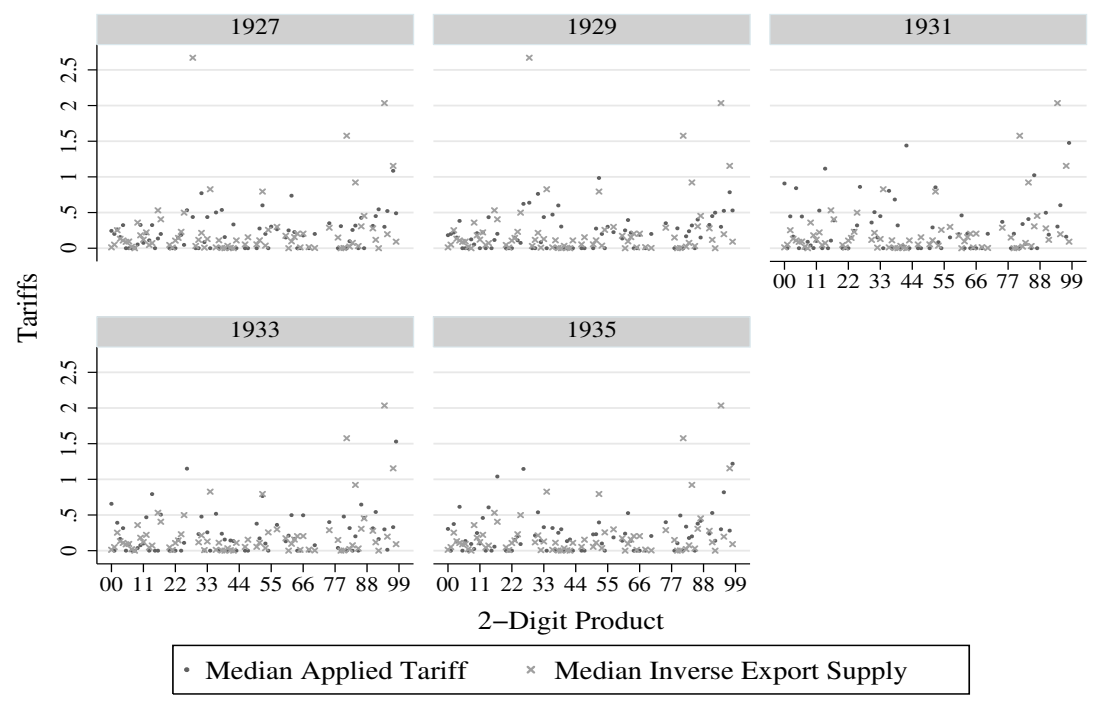

A substantial number of the applied tariffs are close to zero; about 25 percent of the tariff lines/categories were given duty free treatment (about 65 percent of the value of imports) both before and after the passage of the Smoot-Hawley tariff. The duty free list included many goods not produced at home, such as coffee and tea, tin and bananas. For these goods, the United States probably faced a non-infinite export supply function and hence would have benefited from an optimal tariff. In such cases, consumer welfare seems to have mattered more to Congress than any possible terms-of-trade gain and there was no domestic firm or worker lobby to press for these tariffs. What the Smoot-Hawley tariff revision did (by and 
Figure 2: Tariffs Across Industries - Lowess of Medians

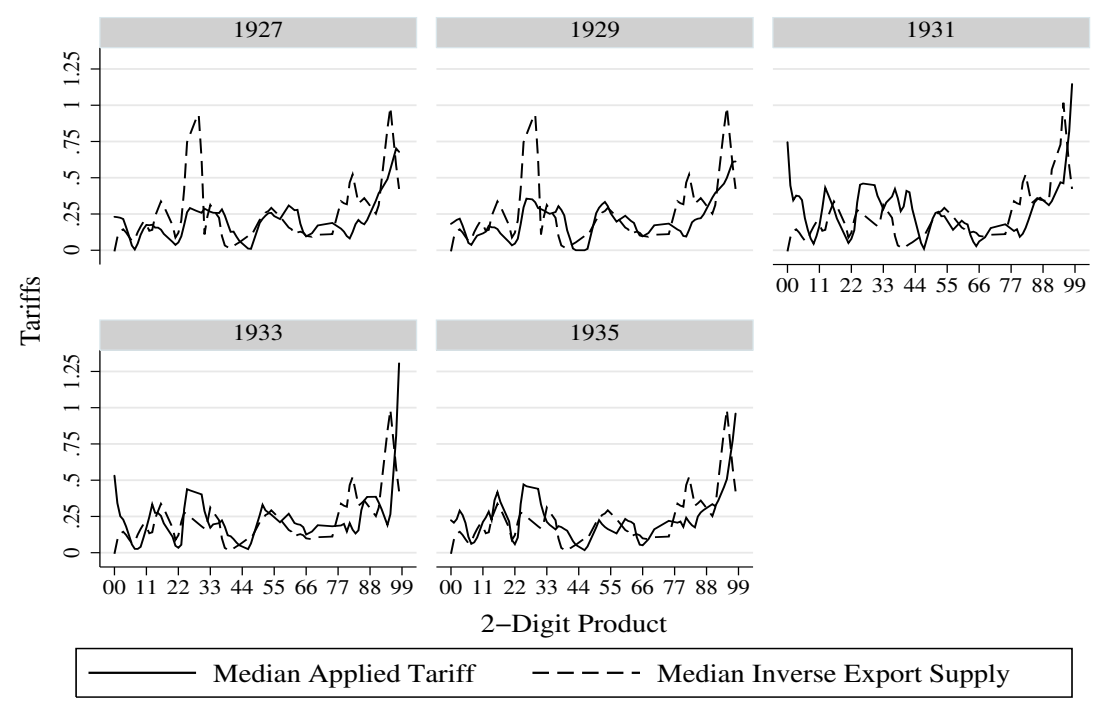

large) was increase tariff rates on the third of imports that were subject to duties rather than shift goods from the duty-free to the dutiable list.

Figure 3: Kernel Density - Levels of Applied Tariffs and Terms of Trade Effects

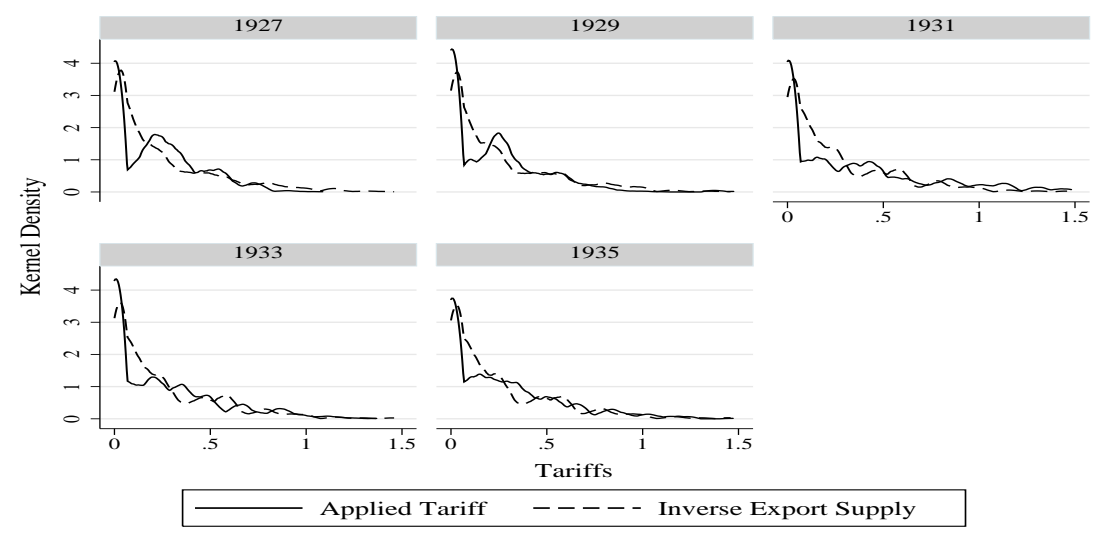

Despite this consideration, Figure 3 presents the kernel densities of the applied and 
Figure 4: Kernel Density - Difference between Applied Tariffs and Terms of Trade Effects

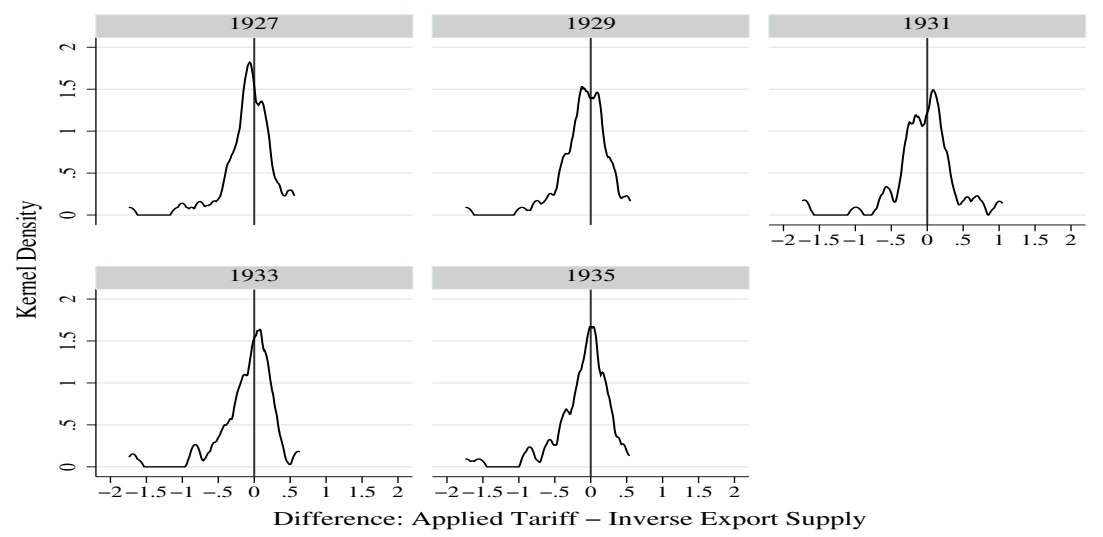

optimal tariffs and shows a close relationship between the two. Figure 4 also shows that the kernel density of the difference between the applied and optimal tariff is still roughly symmetric. The pattern across years in both series is very similar, although the year 1931, the first full year after the tariff change, variation in tariff rates increases in comparison to the late 1920s.

\section{Optimal Tariffs: Market Power and Lobbying}

We now introduce domestic lobbying to our empirical analysis to see how it influences the determination of tariffs at this time. Recall that the politically-optimal tariff from equation (5) - in our use of the term, which includes both terms of trade and worker and firm lobbying influence - is given,

$$
\tau_{k}^{*}-1=\omega_{k}+\frac{\left(I_{k}^{L}-\alpha^{L}\right)+\sigma_{k} I_{k}^{F}\left(1-\alpha^{F}-a\right)}{a+\alpha^{L}} \frac{z_{k}}{\sigma_{k}} .
$$

The politically-optimal tariff includes political economy considerations and will be higher than that justified on terms of trade grounds alone - unless $a+\alpha^{F}>1$, i.e., the government's weight on social welfare and firm contributions to lobbying are sufficiently large.

In terms of data, we have already noted that the "Foreign Commerce and Navigation" 
volumes report the applied ad valorem equivalent tariffs for each good in every other year of our sample. Our lobbying indicators come from testimony before the House Ways and Means Committee and the Senate Finance Committee in 1929, as reported in the published hearings. We have separately classified testimony from industry associations and individual firms as well as labor unions and worker representatives. Lobbying testimony will serve as an indicator of whether firms or workers in an industry $\left(I_{k}^{F}\right.$ and $\left.I_{k}^{L}\right)$ are politically organized. ${ }^{7}$ Table 3 reports summary statistics (indicator mean and count) for the lobbying variables. In addition, the mean and medians for import penetration are also reported (all low, as imports were only about 5 percent of GDP).

Table 3: Lobbying across Industries

\begin{tabular}{|c|c|c|c|c|c|c|c|}
\hline & & Sample & 1927 & 1929 & 1931 & 1933 & 1935 \\
\hline \multirow{3}{*}{$\begin{array}{l}\text { Import Penetration } \\
\qquad\left(z_{k}\right)\end{array}$} & Mean & 0.035 & 0.043 & 0.043 & 0.037 & 0.033 & 0.032 \\
\hline & Median & 0.004 & 0.005 & 0.006 & 0.004 & 0.004 & 0.004 \\
\hline & $\mathrm{SD}$ & 0.090 & 0.103 & 0.098 & 0.090 & 0.082 & 0.076 \\
\hline \multirow{2}{*}{ Total Lobbying } & Indicator & 0.527 & 0.554 & 0.548 & 0.529 & 0.518 & 0.507 \\
\hline & Count & 7.112 & 7.341 & 7.220 & 7.181 & 6.879 & 6.633 \\
\hline \multirow{2}{*}{ National Lobbying } & Indicator & 0.403 & 0.431 & 0.423 & 0.404 & 0.390 & 0.387 \\
\hline & Count & 1.757 & 1.891 & 1.881 & 1.813 & 1.645 & 1.610 \\
\hline \multirow{2}{*}{ Regional Lobbying } & Indicator & 0.237 & 0.242 & 0.243 & 0.241 & 0.230 & 0.221 \\
\hline & Count & 1.852 & 1.876 & 1.824 & 1.853 & 1.796 & 1.706 \\
\hline \multirow{2}{*}{ Firm Lobbying } & Indicator & 0.418 & 0.441 & 0.435 & 0.423 & 0.411 & 0.405 \\
\hline & Count & 3.489 & 3.560 & 3.503 & 3.503 & 3.425 & 3.303 \\
\hline
\end{tabular}

Notes: SD is the standard deviation.

Our estimates of import demand and export supply provide the elasticities $\sigma$ and $\omega$. Finally, we will allow for the possibility that policymakers weight tariff revenue (by $\beta>0$ ) differently than other sources of income. This assumption is salient in this time period as tariff revenue was about 15 percent of federal revenue in the late 1920s and early 1930s.

\footnotetext{
${ }^{7}$ Irwin and Kroszner (1996) also examine the role of industry lobbies in influencing the duties as voted on by the Senate.
} 
We can then rearrange equation (5) into the following estimating equation,

$$
\tau_{k}=\beta \omega_{k}+\Lambda_{1} I_{k}^{L} \frac{z_{k}}{\sigma_{k}}+\Lambda_{2} I_{k}^{F} z_{k}+\Lambda_{3} \frac{z_{k}}{\sigma_{k}}+\epsilon_{k}
$$

where $\tau_{k}$ are observed ad valorem tariffs and $I_{k}^{L}$ and $I_{k}^{F}$ are indicators of worker (national and regional) lobbying and firm lobbying, respectively. Structurally the coefficients $\Lambda$ are each functions of the deep lobbying parameters. Explicitly, estimates of $\Lambda_{1} \equiv \frac{1}{a+\alpha^{L}}, \Lambda_{2} \equiv \frac{1-\alpha^{F}-a}{a+\alpha^{L}}$ and $\Lambda_{3} \equiv \frac{-\alpha^{L}}{a+\alpha^{L}}$ can be combined to uniquely identify the parameters of the model.

Our empirical implementation also draws parallels with Lashkaripour and Lugovskyy (2021). Their model differs from ours as it is a general equilibrium model of trade with scale economies and no lobbying. However, they find an optimal tariff formula with similar characteristics. Matching notation, they show $\tau_{k}^{*}=(1+\bar{\tau}) \omega_{k}+\bar{\tau}$, where $\bar{\tau}$ is the average tariff across sectors in the importing country. Introducing a coefficient in front of the export supply elasticity echoes the mediation of terms of trade effects in general equilibrium shown by Lashkaripour and Lugovskyy (2021). Additionally, firm and worker lobbying data absorbs a portion of the average tariff control they propose. Effectively, we are controlling for general equilibrium effects in the data through our observed lobbying channels.

Table 4 presents the estimates of equation (8) in which the dependent variable (the applied ad valorem tariff) is regressed on the terms of trade and political influence factors. The first column estimates the relationship between applied tariffs and the inverse export supply elasticities, i.e., just a regression with the terms of trade factor $\omega$, which is positively but weakly related to the applied tariff, comparable reduced form analysis such as Broda et al. (2008). Stepping through the channels underlying the optimal tariff, the second column removes terms of trade motives and adds the import penetration-demand elasticities term to look solely at worker lobbying, a specification that mirrors Goldberg and Maggi (1999) and Matschke and Sherlund (2006) who also emphasize the importance of labor groups in tariff determination. Drawing parallels is challenging given the differences in time periods, but our estimates suggest a stronger role of worker lobbying in the 1920s and 1930s than is evident in modern US data. 
Table 4: Elasticities, Lobbying and Tariffs

\begin{tabular}{|c|c|c|c|c|}
\hline \multirow[b]{2}{*}{ Coefficients } & \multicolumn{4}{|c|}{ Ad Valorem Tariff } \\
\hline & $\begin{array}{c}\text { Terms of Trade } \\
\text { no Lobbying }\end{array}$ & $\begin{array}{l}\text { Worker Lobbying } \\
\text { no Terms of Trade }\end{array}$ & $\begin{array}{l}\text { Worker Lobbying } \\
\text { and Terms of Trade }\end{array}$ & Full Model \\
\hline Terms of Trade Weight $(\beta)$ & $\begin{array}{c}0.119 \\
(0.006)\end{array}$ & & $\begin{array}{c}0.116 \\
(0.007)\end{array}$ & $\begin{array}{c}0.115 \\
(0.006)\end{array}$ \\
\hline Worker Indicator $\left(\Lambda_{1}\right)$ & & $\begin{array}{c}2.185 \\
(0.165)\end{array}$ & $\begin{array}{l}1.882 \\
(0.175)\end{array}$ & $\begin{array}{c}1.017 \\
(0.224)\end{array}$ \\
\hline Firm Indicator $\left(\Lambda_{2}\right)$ & & & & $\begin{array}{c}0.705 \\
(0.144)\end{array}$ \\
\hline Import Penetration $\left(\Lambda_{3}\right)$ & & $\begin{array}{r}-0.192 \\
(0.443)\end{array}$ & $\begin{array}{r}-0.435 \\
(0.361)\end{array}$ & $\begin{array}{r}-0.816 \\
(0.411)\end{array}$ \\
\hline \multicolumn{5}{|l|}{ Model Parameters } \\
\hline Government Weight $(a)$ & & 0.370 & 0.300 & 0.181 \\
\hline Fraction of Workers in Lobby $\left(\alpha_{L}\right)$ & & 0.088 & 0.231 & 0.802 \\
\hline Fraction of Firm Contributions $\left(\alpha_{F}\right)$ & & & & 0.126 \\
\hline
\end{tabular}

Notes: Robust standard errors in parentheses.

In column 3 we estimate the model controlling for both terms of trade effects and worker lobbying but still assuming there is no firm lobbying (e.g., $I_{k}^{F}=0$ ). The coefficient estimate $\Lambda_{1}$ suggests that worker testimony in industries with strong import competition results in a much higher applied industry tariff than those where there is no such appearance before the Congressional committees. Given the coefficient estimates we can back out the fraction of workers in the lobby $\left(\alpha_{L}\right)$, which is $\alpha^{L}=0.231$.

The fourth column estimates the full model taking into account terms of trade, worker and firm lobbying. The coefficient estimate $\Lambda_{2}$ is also positive (and statistically significant) but the magnitude is slightly smaller than that of the worker indicator, suggesting that firm lobbying is not quite as influential as worker lobbying. Controlling for firm lobbying increases the estimate of $\alpha_{L}$ to 0.802 , which is now nearly identical to Goldberg and Maggi (1999). We can see the importance of accounting for all of the channels proposed in the full model. The preceding three columns illustrate the contributions of the key channels across industries. Specifically, the importance of worker lobbying falls as terms-of-trade and firm-lobbying motives are included in the model. 
Table 4 also reports the underlying parameters backed-out from the estimated coefficients. In the full model, the government's weight on terms-of-trade factors $(\beta)$ is 0.115 . The implied government weight on social welfare $(\alpha)$ is 0.181 . These parameters are roughly comparable, indicating that tariff levels represent a somewhat greater weighting of social welfare factors over terms of trade factors. This ranking allows us to make sense of the fact that, as noted earlier, many imported goods were given duty-free treatment (benefiting consumers with no direct harm to producers) when there might have been an unexploited terms-of-trade advantage in having a tariff on such goods.

It is difficult to compare our results with those in other papers. One comparable estimate conceptually is government's weight on welfare. ${ }^{8}$ Goldberg and Maggi (1999) estimate a government weight on welfare around 0.98. Our model is different along key dimensions, but if we were crudely match functional forms, our estimate $\alpha=0.181$ implies a government weight in their framework of 0.15 . The specification in column 2 is the same as Goldberg and Maggi (1999), and suggests a higher government weight than the full model, but it is still only 0.27 . This is still a significant level difference, but we find it is sensible given the different time period. Goldberg and Maggi (1999) are estimating a bargaining model for the United States at a time when trade barriers were relatively low (i.e., 1983) and constrained by the GATT, and in which potential terms-of-trade motives for barriers are not considered. It is credible that, given the importance of tariff revenue to the government at the time, the government weight assigned to social welfare (e.g., consumer surplus) relative to welfare generated from sources such as tariff revenues and lobby contributions in the 1930s would be considerably less than the 1980s.

Goldberg and Maggi (1999) do not estimate our $\beta$ as they move export supply elasticities to the right hand side of their specification. But our estimate of the fractions of workers belonging to the lobby, $\alpha^{L}=0.802$, is quite similar to their estimates $\left(\alpha_{L}\right)$, which range from 0.84 to 0.88 . However, we will show these similarities fade after the passage of the Smoot-Hawley tariff in 1930.

\footnotetext{
${ }^{8}$ Our parameter $a$ is equivalent to the Goldberg and Maggi (1999) estimate of they denote as $\frac{\beta}{1-\beta}$.
} 
Other papers also have results that are suggestive in comparison with ours. Ossa (2014) finds that the introduction of lobbying reduces that optimal U.S. import tariff from $60 \%$ to $56 \%$, whereas we find tariffs are higher than optimal as a result of lobbying. Nicita et al. (2018) find that three-quarters of the tariffs set by WTO members are set non-cooperatively. This is somewhat related to our point that about 25 percent of tariff lines/categories are duty free, implying 75 percent of tariffs are set non-cooperatively. (As noted earlier as well, our estimate of the optimal tariff is very similar to theirs.)

Figure 5: Optimal Tariff Comparison

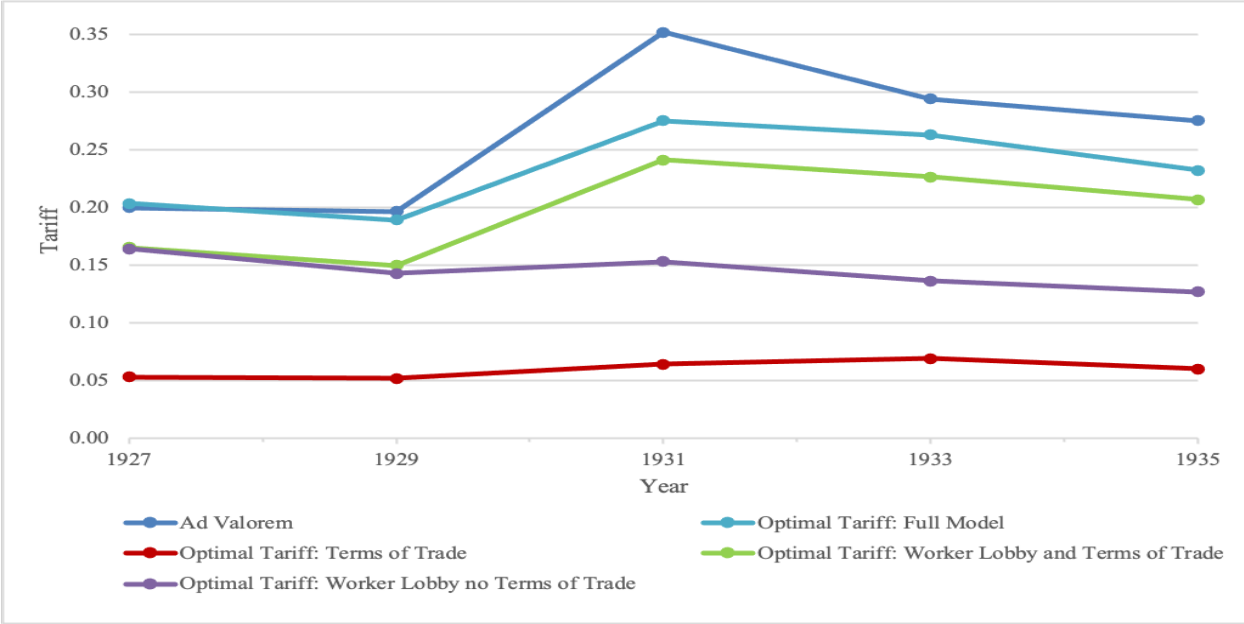

Figure 5 provides a visual comparison of the models from Table 4. Here we predict the optimal tariff for each of the specifications for every industry in the data. We then plot the average predicted politically-optimal tariff against the average applied ad valorem tariff over time. The importance of controlling for lobbying and terms of trade is evident, especially post-Smoot Hawley. Pre-Smoot Hawley, worker lobbying appears to reasonably explain applied tariffs, but cannot match the dramatic increase in protectionism following Smoot-Hawley without accounting for terms-of-trade effects.

Table 5 explores this differences across time periods empirically and reveals some interesting patterns in separating the estimates by pre- and post-Smoot Hawley. The weight on the term-of-trade impact of tariffs is roughly similar in the two periods, but the coefficient 
on the worker indicator increases, much more so that the firm indicator. This makes sense in that the Smoot-Hawley tariffs were finalized as the United States had begun to slip into the Great Depression, when unemployment was rising and political sensitivity to labor was probably higher. The indicator on import penetration is also lower, as foreign competition was declining as imports fell faster than GDP with the onset of the Depression. One interesting finding is that the government's weight on social welfare (profits, wages, revenue) is much higher after Smoot-Hawley than before; in fact, the weight more than doubles. This suggests that the Smoot-Hawley tariff was not imposed for terms-of-trade reasons (the weight on the terms of trade does not change much, as noted) but for other reasons.

Table 5: Elasticities, Lobbying and Tariffs

\begin{tabular}{lccc}
\hline & \multirow{2}{*}{ Dependent : Ad Valorem Tariff } \\
\cline { 2 - 4 } & & \multicolumn{2}{c}{ Smoot-Hawley } \\
\cline { 2 - 4 } Coefficients & Pooled & Pre & Post \\
\hline Terms of Trade Weight $(\beta)$ & 0.115 & 0.099 & 0.125 \\
& $(0.006)$ & $(0.008)$ & $(0.009)$ \\
Worker Indicator $\left(\Lambda_{1}\right)$ & 1.017 & 0.872 & 1.215 \\
& $(0.224)$ & $(0.241)$ & $(0.371)$ \\
Firm Indicator $\left(\Lambda_{2}\right)$ & 0.705 & 0.641 & 0.739 \\
& $(0.144)$ & $(0.152)$ & $(0.250)$ \\
Import Penetration $\left(\Lambda_{3}\right)$ & -0.816 & -0.850 & -0.524 \\
& $(0.411)$ & $(0.436)$ & $(0.723)$ \\
\hline Model Parameters & & & \\
\hline Government Weight $(a)$ & 0.181 & 0.172 & 0.392 \\
Fraction of Workers in Lobby $\left(\alpha_{L}\right)$ & 0.802 & 0.975 & 0.431 \\
Fraction of Firm Contributions $\left(\alpha_{F}\right)$ & 0.126 & 0.093 & 0.001 \\
\hline Notes: The Smoot
\end{tabular}

Notes: The Smoot-Hawley periods are defined as $\mathrm{Pre}=\{1927,1929\}$ and Post $=\{1931,1933,1935\}$. Robust standard errors in parentheses.

To shed some light on this idea, Figure 6 decomposes the tariff into the terms of trade component and the worker and firm lobby components. In other words, we take the parameter estimates and the implied lobbying parameters for year and calculate the contribution of each factor to the political-optimal tariff of that year. Panel (a) shows the levels of the 
Figure 6: Politically Optimal Tariff: Decomposition

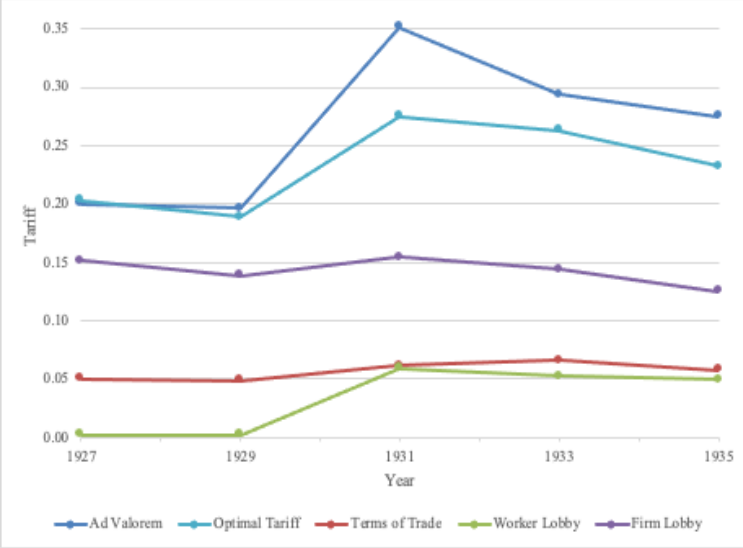

(a) Applied and Optimal Tariffs in Levels

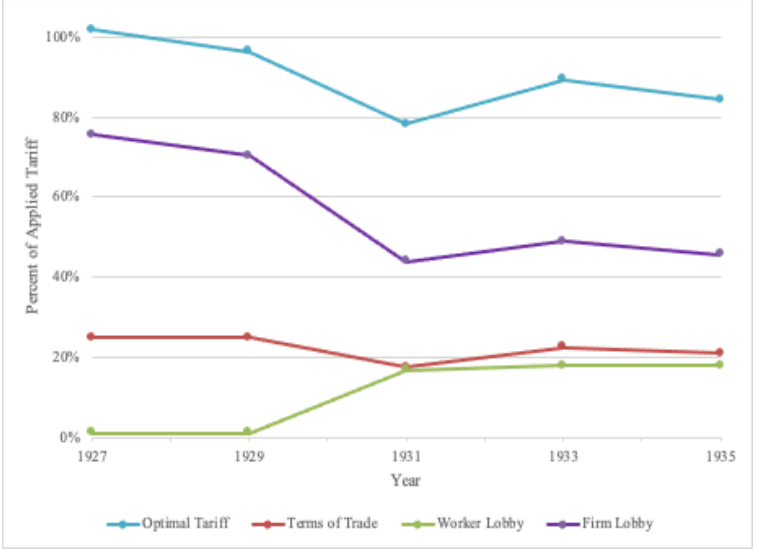

(b) Applied Decomposed by Optimal Tariffs

tariffs that can be attributed to each factor and panel (b) shows the percentage contribution of each factor. Before and after the imposition of the Smoot-Hawley tariff of 1930, about $20 \%$ of the tariff level is accounted for by terms of trade considerations. This makes sense in that there was a weak but positive correlation $(+0.1)$ between $\omega$ and the applied tariffs. Prior to 1930, most of the tariff level - about three quarters, according to these calculations - is determined by firm lobbying, consistent with the discussion in Schattschneider (1935) and Irwin (2011). However, after 1930, the proportion of the tariff that is accounted for by firm lobbying declines and that accounted for by worker lobbying increases. As mentioned earlier, this could be explained by an increase in Congressional sensitivity to worker concerns with the onset of the Great Depression. Thus, the changes in the tariff rates in the Smoot-Hawley legislation were not dictated by new terms-of-trade considerations, which were relatively constant during this period, but by firm and worker lobbies. Both firm and worker lobbying taken individually are more important than terms of trade factors in the setting of rates. Many of the existing factors that affect tariff setting were already built into the base rates; the changes appear to have been driven from increased consideration to lobbying from labor groups. 


\section{Conclusions}

This paper has provided an integration study of tariff setting that incorporates terms-oftrade motives and political economy factors during a period in which the United States had complete discretion in setting tariff rates, unconstrained by cooperative trade agreements. We find that both terms-of-trade and political-economy factors were at work in determining the tariff schedule in the late 1920s and early 1930s, although political-feconomy considerations dominate. The standard optimal tariff of the United States was around 14 percent (median) but such factors only account for about 20 percent of the tariff level. After 1930, lobbyists representing labor groups were more important sources of tariff setting, as one might have expected with the onset of the Great Depression.

\section{References}

Bagwell, Kyle and Robert Staiger, "What do trade negotiators negotiate about? Empirical evidence from the World Trade Organization," The American Economic Review, 2011, 101 (4), 1238-1273.

_ , Robert W Staiger, and Ali Yurukoglu, "Multilateral Trade Bargaining: A First Look at the GATT Bargaining Records," American Economic Journal: Applied Economics, 2020, 12 (3), 72-105.

Broda, C, N Limão, and David Weinstein, "Optimal tariffs and market power: the evidence," The American Economic Review, 2008, 98 (5), 2032-2065.

Broda, Christian and David Weinstein, "Globalization and the Gains from Variety," The Quarterly Journal of Economics, Jan 2006, 121 (2), 541-585.

Feenstra, Robert C, "New Product Varieties and the Measurement of International Prices," The American Economic Review, 1994, 84 (1), 157-177.

Goldberg, Pinelopi and Giovanni Maggi, "Protection for Sale: An Empirical Investigation," The American Economic Review, Dec 1999, 89 (5), 1135-1155.

Grossman, Gene and Elhanan Helpman, "Protection for Sale," The American Economic Review, Sep 1994, 84 (4), 833-850.

_ and _ , "Trade Wars and Trade Talks," Journal of Political Economy, Aug 1995, 103 (4), 675-708.

Irwin, Douglas A, "Changes in U.S. Tariffs: The Role of Import Prices and Commercial Policies," The American Economic Review, September 1998, 88 (4), 1015-1026.

_, Peddling Protectionism: Smoot-Hawley and the Great Depression, Princeton University Press, January 2011.

_, Clashing Over Commerce: A History of U.S. Trade Policy, University of Chicago Press, November 2017. 
Irwin, Douglas A. and Randall S. Kroszner, "Log-rolling and economic interests in the passage of the Smoot-Hawley tariff," Carnegie-Rochester Conference Series on Public Policy, December 1996, 45 (1), $173-200$.

Lashkaripour, A and V Lugovskyy, "Scale economies and the structure of trade and industrial policy," Mimeo, 2021.

Maggi, Giovanni and Andrés Rodríguez-Clare, "A Political-Economy Theory of Trade Agreements," American Economic Review, 2007, 97 (4), 1374-1406.

Matschke, Xenia and Shane M Sherlund, "Do Labor Issues Matter in the Determination of U.S. Trade Policy? An Empirical Reevaluation," American Economic Review, 2006, 96 (1), 405-421.

Mitchener, Kris James, Kirsten Wandschneider, and Kevin Hjortshøj O'Rourke, "The SmootHawley Trade War," NBER Working Paper, 2021.

Nicita, A, M Olarreaga, and Peri Silva, "Cooperation in WTO's tariff waters?," Journal of Political Economy, June 2018, 126 (3).

Ossa, Ralph, "Trade Wars and Trade Talks with Data," American Economic Review, December 2014, 104 (12), 4104-4146.

Schattschneider, E. E., "Politics, pressures and the tariff," New York: Prentice Hall, 1935.

Soderbery, Anson, "Estimating Import Demand and Supply Elasticities: Analysis and Implications," Journal of International Economics, 2015, 96 (1), 1-17. 